\title{
A DFA-Based Wood Frame Furniture Design Using Quality Function Deployment: A Case Study in School Open Spaces
}

\author{
Ouyang, Chi \\ Assistant Professor, Dept. of Architecture \\ National United University \\ Miaoli, Taiwan, R.O.C \\ 000049@nuu.edu.tw
}

\author{
$\mathrm{Wu}$, Kuei-Yang \\ Professor, Dept. of Architecture \\ National United University \\ Miaoli, Taiwan, R.O.C \\ kyw@nuu.edu.tw
}

\begin{abstract}
With more and more schools expanding and redesigning their landscape spaces, therefore their outdoor furniture's shape, dimension, quality and usage are also changing and redesigning. One of the significant changes in the design process is to take users' needs/concerns into account. This change is influenced by a community-based design concept found in public spaces design.

In this paper, we propose a Design for Assembly (DFA) Procedure which is focus on examining the past practice of outdoor wooden furniture design in campus spaces by using Quality Function Deployment (QFD) to fill in this missing link.

The employment of different matrices to capture the relationship between the voice of customer (VOC) and subsequent design and quality characteristics compose an evaluation framework suitable to fill the gap in the assembly procedure of outdoor wooden frame furniture. The study also produces several insights applied on outdoor wooden furniture design in campus space.
\end{abstract}

Keywords- Outdoor furniture; QFD; Design for Assembly

\section{INTRODUCTION}

In Taiwan, the fast economic and population growth in the past 30 years has resulted in rapid urbanization all over the country [1]. Public green areas, such as parks, squares, parkways, campus and so forth, are the major outdoor spaces for residents in the neighborhood to take a walk or engage in recreation and social activities. The thermal comfort level of an outdoor space can clearly influence its usage by people [2]. In the Scope of Social Architecture (1984), Hatch describes an international movement based on the conviction that participation is crucial to the redirection of architecture and the city it creates. Social architecture is viewed as an instrument for

transforming both the environment and the people who live in it [3].

As for the campus, it becomes significant resources, like health care, science and technology, etc. for surrounding communities; they affect people's lives by providing diverse social, economic, and cultural activities. It is easy to see the importance of campus landscape and its impact on how people use such spaces.

As a public space, campus landscape space is vital to students, faculty and staff, and community members who utilize the space. Research and studies have discussed how students, faculty, staff, and members in community use outdoor furniture in campus spaces based on the areas of environmental behavior and environmental perception.

\section{RESEARCH METHODOLOGY}

This research is organized into four phases. This section presents the background of the research - why it is important to address the design of outdoor furniture, current design considerations, and the need for a new design paradigm. It also shows the questions and challenges addressed in this research. A case study is presented in Section 3 to demonstrate the use of QFD in the outdoor furniture design. Section 4 contains an analysis and discussion of Design for Assembly Design in furniture design based on the case study. All the findings are summed up in the final section.

The methodology used in the project presented is shown in Figure 1.

We focus on the design process of importance in the users' involvement which involves the users' input and provides a framework that can link to design attributes. Quality Function Deployment (QFD) is a framework widely used in industries (including manufacture and service). This research addresses the applicability of QFD, and its benefits and limitations in outdoor furniture and product design. A case study is provided to demonstrate the use of QFD in outdoor furniture design. A discussion section follows the case study to address the pros and cons of using QFD in the design of outdoor furniture.

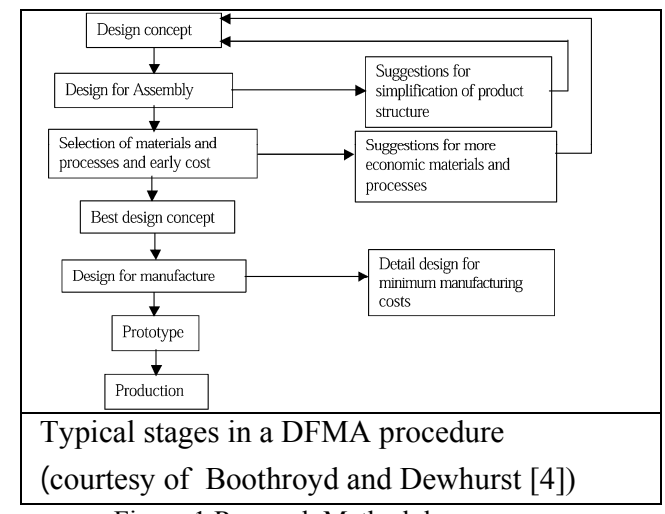

Figure 1.Research Methodology 


\section{EMPIRICAL PROJECT}

In the empirical project, two wood frame units are installed in two places to match with the surrounding environmwent. The structure of the outdoor furniture is wood light frame construction structure. The furniture has rough writing surfaces, falls apart quickly, and does not fit the children, yet it is relatively costly and consumes a disproportionate amount of limited educational budgets. The project is identifying the most important variables in order to create designs that are ergonomically correct, strong, durable, low maintenance, low cost, and can be made by local industries from locally available materials. The original sturcture is in an elementary school located in Township Zhong Ping Village with agriculture as the main industry. Currently, the village still retains the traditional patterns of rural and gives people the feeling of pure simplicity.

In this project, we used the wood frame structure to build the deployable 14 models. Each model is $60 \mathrm{~cm}$ wide and $240 \mathrm{~cm}$-long. The passage is about $14.5 \mathrm{~m}$ long. These concepts of wood frame structures are created and simulated in computer and then installed in two places. The original design is located in an elementary school and a refined design is placed in the university (NUU) campus (Figure 2).

\begin{tabular}{|l|}
\hline $\begin{array}{l}\text { A. Create the concept of } \\
\text { deployable wood } \\
\text { frame unites in computer } \\
\text { simulation. }\end{array}$ \\
B.Wooden frame unites study \\
$\begin{array}{l}\text { C. On-site installation. } \\
\text { Case1. Elementary School } \\
\text { Case2. NUU Campus (Refined } \\
\text { Design) }\end{array}$ \\
\hline
\end{tabular}

Figure.2 Wood frame units assembling procedure

These 14 models combine together as one roof and each three models contains one chair that suitable for the different age's children ergonomic. It's for the children to do their activities and some other social works, and it is a very little space but becomes the new open space for school.

\section{QFD AND HOQ}

QFD was developed initially by Akao in Japan in 1966. Akao (1990) defined it as "a method for developing a design quality aims at satisfying the customer and then translating the customer's demands into design targets and major quality assurance points to be used throughout the production stage. [5] This method is used in many design fields for various purposes, and it is used at the early investigation and later evaluation stages of a project in order to make more accurate decisions in terms of design quality and client's needs. QFD is capable to lead innovation product designs.

An innovative product development process requires an understanding of continuously changing customer wants and needs. Hence, there is a need to study and develop procedures that can help a company or project team gain a profound knowledge of customer requirements (CR) and satisfaction, and then develop products with innovative features.

QFD is a very powerful and complex instrument. A four-phase approach is accomplished via a series of charts that guide activities of a product team by providing standard documentation during product and process development. "Figure 3."

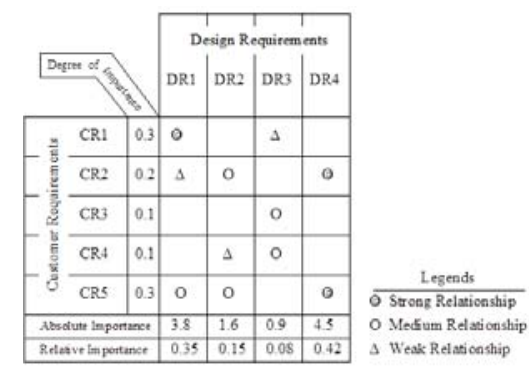

Figure.3. A Typical HOQ Matrix with a 1-3-9 Rating Scheme [6].

\section{A. Furniture Design Using Quality Function Deployment in School Open Space}

In this research, the application of QFD process is examined by following the process in a case study on the furniture design in school open space design. This is to demonstrate the value of adopting QFD in design process that will enable design architects to better understand the users' need and provide a prioritized design attributes that would help designer in the design.

The design process using QFD:

- Define the users/customers.

- Acquire user needs, and design requirements.

- Rank user needs and design requirements.

- Generate conceptual design and design attribute

- Construct correlation matrix, linking requirements/needs to design attributes

- Characteristic plan matrix

It is often iterative and continuous in practice. Following is the case study of furniture design using QFD.

\section{B. Define the users/customers}

The first step is to identify the users. Faculty, staffs, parents, visitors and surrounding community members are also important users.

\section{Acquire User Needs}

This is the most crucial step of the QFD process. It involves the identification of what end-users needs. Several methods can be used to establish customers' expectations such as survey, interviews; questionnaires; observation and community meetings, etc. From the survey, the major findings include what are the most needed features or functions. The needs considered most by the users are: Natural, Sitting Places, Activities, Safety and Art .

Based on the survey results, the 14 kinds of users' needs for elementary school's open space are shown in Table.1. 
TABLE 1. RANKING OF USER'S NEEDS

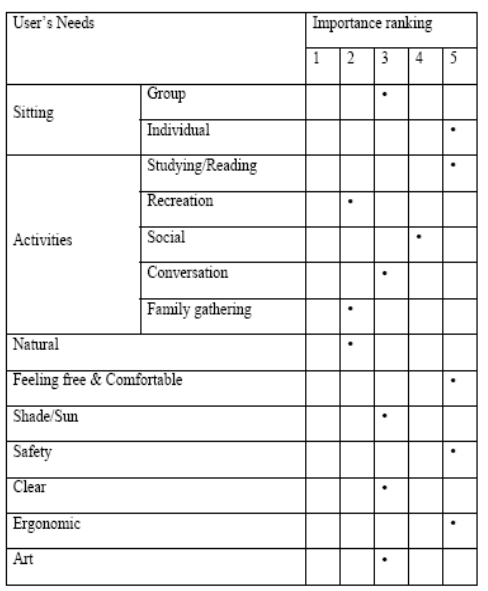

\section{Identify design attributes}

As reviewed in the previous section, QFD usually consist a series of HOQ. The first HOQ tracks user needs to quality functions; the second HOQ will "translate" the quality functions to design features; then the design features to construction (manufacture). We combine the user needs with quality functions as the "What" elements. As "How" elements in QFD are used to specify the design features of the respective "What" element.

\section{E. Development of correlation matrix}

An important step in the QFD process is the development of the correlation matrix. This correlation matrix shows the relationship between the "What" list and the "How to" list. For example, users' need "Safety" in the "What" list, is strongly correlated with the design attributes such as standing and plan in the ergonomic item. The strength of the correlation could also be described as strong, medium or weak and can be quantified as 5, 3 and 1. (See Table.2)

TABLE 2. Correlations between User's Needs and Design Features.

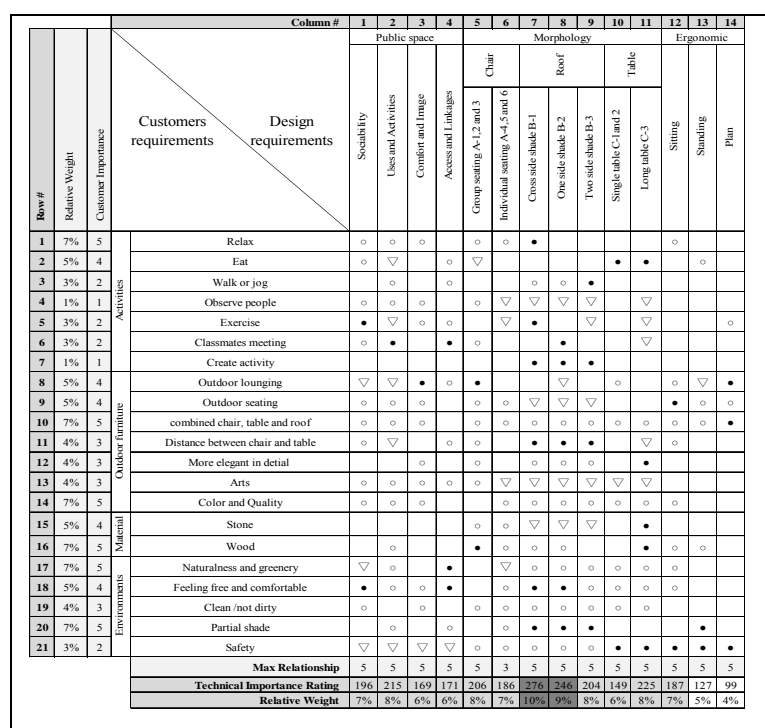

\section{CONCLUSION}

\section{A. Design for Assembling Procedure}

Finally, we can see that, although they are located in different places, the projects of elementary school and NUU have common processes and concerns. The process is based on the six ordered steps as shown in Table3,4,5.

TABLE 3. QFD Applies in DFA Procedure

\begin{tabular}{|l|l|}
\hline Step1. & Elementary School \\
Case study & Activity Space \\
\hline Step2. & \\
\hline Step3. Analyze & QFD VOC \\
Method & \\
\hline Step4. & Furniture Design \\
Product & \\
\hline Step5. & Conclusion \\
Result & \\
\hline Step6. & NUUCampus \\
Refine Design Case & \\
\hline
\end{tabular}

TABLE 4. Concerns of refine design

\begin{tabular}{|l|l|l|l|}
\hline Parts & A. Furniture & B. Space & C. Customer \\
\hline Concerns & 1. Surface & 1. Activity & 1. Requirements \\
\cline { 2 - 4 } & 2. Material & 2. Aesthetic & 2. Satisfaction \\
\cline { 2 - 4 } & 3. Quality & 3. Usage & 3. Involvements \\
\cline { 2 - 4 } & 4. Ergonomic & 4. Public & 4.Design development \\
\cline { 2 - 4 } & 5. Comfortable & 5. Naturalness & 5. Community \\
\hline
\end{tabular}

\section{B. The First HOQ matrix}

As we can see on the table, "Morphology -Roof Cross side shade B-1" is close related with the items such as "relax", "exercise", "create activity", "distance between chair and table", "feeling free and comfortable" and "partial shade". In addition, "Morphology -Roof -One side shade B-2" also obtain high percentage scores.

TABLE 5. Result of first HOQ

\begin{tabular}{|c|c|c|c|}
\hline $\begin{array}{l}\text { High } \\
\text { /low } \\
\text { scores }\end{array}$ & Name & Percentage & $\begin{array}{l}\text { Mostly related to } \\
\text { VOC (5 point) }\end{array}$ \\
\hline \multirow[t]{2}{*}{$\begin{array}{l}\text { High } \\
\text { scores }\end{array}$} & $\begin{array}{l}\text { Morphology } \\
\text {-Roof- } \\
\text { Cross side } \\
\text { shade B-1 }\end{array}$ & $10 \%$ & $\begin{array}{l}\text { Relax, Exercise, } \\
\text { Create activity, } \\
\text { Distance between } \\
\text { chair and table, } \\
\text { Feeling free and } \\
\text { comfortable, Partial } \\
\text { shade }\end{array}$ \\
\hline & $\begin{array}{l}\text { Morphology } \\
\text {-Roof-One } \\
\text { side shade } \\
\text { B-2 }\end{array}$ & $9 \%$ & $\begin{array}{l}\text { Classmates meeting, } \\
\text { Create activity, } \\
\text { Distance between } \\
\text { chair and table, } \\
\text { Feeling free and } \\
\text { comfortable, Partial } \\
\text { shade }\end{array}$ \\
\hline \multirow[t]{2}{*}{$\begin{array}{l}\text { Low } \\
\text { scores }\end{array}$} & $\begin{array}{l}\text { Ergonomic } \\
\text {-Standing }\end{array}$ & $5 \%$ & Partial shade, Safety \\
\hline & $\begin{array}{l}\text { Ergonomic } \\
\text {-Plan }\end{array}$ & $4 \%$ & $\begin{array}{l}\text { Outdoor lounging, } \\
\text { Combined chair, } \\
\text { Table and roof safety }\end{array}$ \\
\hline
\end{tabular}


Based on the VOC, the items of users' need with the hight scores in first HOQ matrix's should be considered in advance. It can be found that the the two roofs got more percentages values than others. Therefore, we should consider redesigning the NUU campus's old chairs according to the VOC and to put plastic roof on it as the following projects.

As for the items of users'needs with lower percentage values such as ergonomic standing and plan. It might be due to the related VOC items are too few to be considered by the users. However, the ergonomic items always play good roles in building furniture design after all.

\section{REFERENCE}

[1] Huang, S.C.L., A study of outdoor interactional spaces in high-rise housing, Journal of Landscape and Urban Planning, 2006, 78(3): 193-204.

[2] Lin, T.P.,Thermal perception, adaptation and attendance in a public square in hot and humid regions, Building and Environment, 2009, 44(10): 2017-2026
[3] Sanoff, H., Community participation methods in design and planning.USA, AIA, 2000.

4] Boothroyd, G, Dewhurst, P, and Knight, W, Product design for manufacture and assembly, Computer-Aided Design 1994, 26(7): $505-520$.

[5] Akao, Y.,Quality function deployment: Integrating customer requirements into product design, translated by Mazur, G.H., Productivity Press, Cambridge, MA,1990.

[6] Huat, C.B., Edwards,N., Public space: design, Use and management. National University of Singapore. Centre for Advanced Studies, 1992.

[7] Kamara, J., Anumba, C., and Evbuomwan, N, Client requirements processing in construction: A new approach using QFD Architectural Engineering, 1999, 5(1): 8-15.

[8] Danie,L. M., Winter bottom wood in the landscape.2000, New York: John Wiley \& Sons.

[9] Franceschini, F., A rating scales and prioritization in QFD, International Journal of Quality \& Reliability Management, 1999,16(1): 85 - 97

[10] Marvin, E. Gonza'lez, G.Q., and Bahill, A.T., Improving product design using quality function deployment: The school furniture case in developing countries, Quality Engineering, 2003, 16(1): 45-56. 